\title{
The Effect of Organizational Innovation and Organizational Learning on Organizational Performance
}

\author{
MOHAMMAD DAUD ALI \\ Lecturer, University of Haripur, Haripur \\ daudalikhan725@gmail.com \\ DR. SYED IMAD SHAH \\ Institute of Management Studies, University of Peshawar \\ DR. SHAHID JAN \\ Associate Professor, Abdul Wali Khan University, Mardan \\ shahidjan@awkum.edu.pk \\ MUHAMMAD ILYAS \\ Lecturer, Abdul Wali Khan University, Mardan \\ Milyas_85@awkum.edu.pk
}

\begin{abstract}
This research tries to investigate the influence of organizational learning on innovation on one hand and the impact of innovation on performance on the other. Upon the review of literature, two hypotheses projected in pursuit of the research: the positive impact of organizational learning on innovation as well as the co relational effect of innovation with performance. Data was obtained distributing questionnaires in five public sector universities of Peshawar, Khyber Pakhtunkhwa, Pakistan. Conclusions substantiate hypotheses thus provided additional substantiation that organizational learning has a say in innovation capacity, and also the fact that innovation is positively associated to organization learning $\left(R^{2}=0.65\right)$ and coefficient $\beta$ is 0.31 this clearly show that innovation leads to organization learning, on the other hand organization learning has positively associated to organization performance $\left(R^{2}=0.70\right)$ and coefficient $\beta$ is 0.54 this means that organization learning leads to organization performance, and has positive significant effect on financial performance.
\end{abstract}

Keywords: Organizational learning, Innovation, Performance

\section{Introduction}

In Pakistan the organizations still have those outdated and stagnant methods which were in practice since the very existence of these organizations. The somewhat techno_ phobic environment in the organizations always has resisted the innovations and the latest techniques. Because of this very reason the overall efficiency of the organization is lowered and the employees develop grievances against each other as they do identical jobs for years and the organizational learning is not given due importance, hence feel bored and uneasy. When certain innovations are brought about, the overall 
output can be improved and the employees can be equipped with the latest techniques. The communication gap created by the red taps can be overcome by the latest communication tools and immediate result can be made possible, overcoming the hindrances in the activities which will improve performance of the employees in the organization.

\subsection{Research Objectives}

The objective of the proposed study is to find the importance of learning and innovation in the organizations. The revelation of the New Technology like the internet bringing the various innovations in the organizations with a view to enhance the output is yet another pragmatic objective of the study.

- To find out the impact of organizational learning on organizational innovation.

- To find out the influence of organizational innovation on organizational performance.

\subsection{Research Questions}

The following questions are to be discussed in the current study and research:

- What role can organizational innovation play in increasing the organizational performance?

- How organizational learning can improve organizational innovation?

\section{Literature Review}

The literature on innovation is varied and this literature chapter shall walk around and vitally analyze a variety of such literature, models and theories to supply an analytical cornerstone for audit of the science articles. The Innovation science has emanated from areas of knowledge in a varied nature like administration, psychology, economics and sociology. In these and these like disciplines, scientists inclined to conceptualize novelty/innovation in varied conduct (Gopalakrishnan \& Demanpour 1997; Tang 1998). This literature stresses to amalgamate and synthesize prevailing innovation science to supply several pragmatic thick morals for administrators; this literature is chosen for its concentrate on organizational unit. Adisguised character of innovation is that innovation ought to be valuable (Gronhaug \& Kaufman 1988; Padmore, Schuetze \& Gibson 1997; Cooper 1998). One important spot of argument is to find whether innovation is a process, or it is a consequence (Ettlie, 1980; Kimberly \& Evanisko 1981; Rodgers 1983).

\subsection{Dimensions of Innovation}

The above and other such troubles in effort to define innovation may also be associated to the various proportions of inventions. Few of them are types, stages and level of analysis of innovation, (Gopalakrishnan \& Damanpour 1997).

\subsection{Innovation Types}

Three breeds of innovation diagnosed via Gopalakrishnan and Damanpour (1997) are, radical v/s incremental, scientific v/s administrative and products v/s processes. Product innovation are tangible yield of institute, like the Gillette's fresh Mach III shaving blade. But process innovation contributes to yield commodities and services as a result of the inputs. For instance SPC's new engineering processes approving the potting fruit in new plastic dishes. On a variety, innovation is reported as incremental to essential based on the grade of variation necessary to realize and execute innovation (Cooper 1998). Scientific innovation is immediately associated to presentation of a 
commodity, e.g., a fresh chemical practice, a fresh article of software. The administrative innovation however recount to administration activities such as framework, personnel functions, and the accounting organism.

\subsection{Innovation Phases}

The phases of innovation may be widely placed in two separate stages, creating and adopting of innovation (Gopalakrishnan \& Damanpour 1997). Creation embraces notion, invention and burden unravel for commodity or process solving whereas adoption phase indicates the execution and/or realization of the innovation. Organizations can undertake either one, main in a specified segment, or involve in both.

\subsection{Levels of Analysis}

Innovation is researched nationwide, industry, organizational, team or person. Every horizon can shape the conceptualization of innovation. The size and the troubles talked about earlier underscore the scale for inconsistency in innovation description based on the eye of the investigator, the size to which innovation researched and purpose of query. This study shall scene innovation as of the standpoint of the institute and prefers an open and multi-dimensional loom as this corresponds with the company oriented purpose, is added indication of present day versatile institute and allows this inquiry comprise a broad range of science from where to origin several overall principles of innovation. This is assessed concisely, nonetheless sufficiently broad to include actions of an enterprising nature happening in organizations.

\subsection{Innovation Theory}

At current there is not a simple and single theory of innovation. Because there are complication, regardless vast research from a lot of fields, is to unite all the bets and pieces of thinking into a single theory. The Innovation is a kind of action of more intricacy than it looks. The frequently alike theme gathered from the institute data shows that the results are not contradictory (Wolfe1994, p. 405). For the reason that scientists represent many dissimilar fields, frequently research particular apparatus of innovation, and emphasize various size, a merge overall theory is hitherto to surface. A lot of scientists think overall theory is hopeless because of numerous intricacies of innovation (Abramson 1991; Eveland 1991, mentioned in Wolfe 1994 p. 406). As long as a by and large innovation theory is not available, this literature shall embrace networks theory as an outline for debate. As Amabile (1988, p. 163) refers to, the process of organizational innovation is however exercised at horizontal; a great figure of persons laboring jointly in unlike cells on unlike features of overall issue of bringing about a fresh idea.

System is a team of small units' labor jointly as an interconnected sum total (Briggs 1992). The networks scene manages the elements of a strict as key in, processes, outputs and examines the correlation (Vecchio, Hearn \& Southey 1998). Adding to it, The General Systems Theory was devised via Ludwig von Bertalanffy, the German Biophysiologist, in 50s (Hatch 1997). His concept was a bid to amalgamate subjects of science to recount scientific occurrence from one single bit to an entire society which is all allied throughout a chain of command of networks (Hatch 1997). Each upper horizontal scheme is written of cheaper level schemes (Cummings \& Worley 1997). So an institute, e.g., is a structure staying in a super-system of entire company and is written of secondary-systems like partitions and sections. Any one of these floors relates and has impacts on each other. Several models are built for process innovation, e.g. Tang (1998), 
Cooper (1998), Padmore et al. (1997), Klein \& Sorra (1996).

\subsection{Hypotheses}

\section{$\boldsymbol{H}_{1}$.The learning capability of Organization is directly correlated to organizational} innovation.

\section{$\boldsymbol{H}_{2}$. Organizational innovation has a significant correlation with organizational performance.}

Organizational research center on the learning foundation have by the governing body and engendered in organizational study (Cohen \& Levinthal, 1990; Nonaka \& Takeuchi, 1995). Organization studying is an important tactical factor/variable for businesses that look for to steer in new yield or bring ahead latest markets as a desire of innovating endlessly in rank to endure forceful struggle (Cefis \& Marsili, 2005).Consequently, it is obligatory to stir developing elements that augment to research and empower the beginning of new ideas, services products, and procedures before competitors (Lloréns, Ruiz \& Garcia, 2005).The learning supports creativity, encourages fresh learning ,thoughts and grow the capability to understanding and askance, privileges executive smartness and configurations a setting for point of reference to the OI (García, Ruiz \& Llorens, 2007, p. 535).The towering stages of consignment of learning accredits to bigger innovative direction and pursuit (Ussahawanitchakit,2008).upon the basis of these ranks of differences, we put forward our hypothesis that The diffusion of research books approves the scenery that research is most valued indicator of firm recital as a effect of progression of competent surroundings (Wheelwright and Clark, 1992;Bueno and Ordoñez, 2004).The Innovation may result in advanced market share, bigger goods produced competence, higher productivity expansion, and advanced profits (Shefer \& Frenkel, 2005). As per the study of Zahra, Ireland \& Hitt (2000), research empowers businesses to put forward bigger type of distinguished yield that enhance fiscal feat and outputs. Despite the optimistic bond between research and recital stated in the earlier research, the bond amongst firm's research potential and recital does not possess any decisive verdict. For instance, Kemp et al. (2003) encountered that research was linked with earnings and paid job expansion, not productivity and profit amongst firms in Holland. Also similar is, Zhou, Tan and Uhlaner (2007) encountered no optimistic issue of research (product and new service) in Netherlands companies. Consequently, to farther investigate the attachment between firm's research capacity and performance.

Innovations can be categorized both as inventions and adoption. They exist in many shapes and differ in intricacy and extent. Enterprises in their venture to make a more income cannot prevail for quite long span of time but being aggressively innovating. Otherwise, their Customers will quit them and switch to more novel and fresh products or services of the competitor firms. It is a pragmatic fact that in an endeavor to improve their performance companies ride on innovation differently. Innovation strategy indicates and measures the degree to which a firm attempts to use innovation to implement its strategy and get better performance. Sometimes however Innovation is discussed in a restricted sense to signify inventions only (products, services, or procedures that no company has yet introduced). Mostly, it applies in a broad sense that encompasses both invention as well as imitation (incorporating strategies to introduce product, service or process that may not be an invention rather is first time brought to this organization). In our study the term applied in this broad sense. A model given as below can be sorted out 
to help understand the positive relationship of the variables.

\subsection{Models for step}

wise multiple regression

analysis

\section{Model for first regression \\ equation......}

\section{Organizational learning \\ Committed to learning \\ Share vision \\ Open mindedness \\ Intra-Org-Knowledge sharing \\ \}}

\section{Organizational} innovation

Technical innovation

Market innovation

\section{Model for second regression} equation......

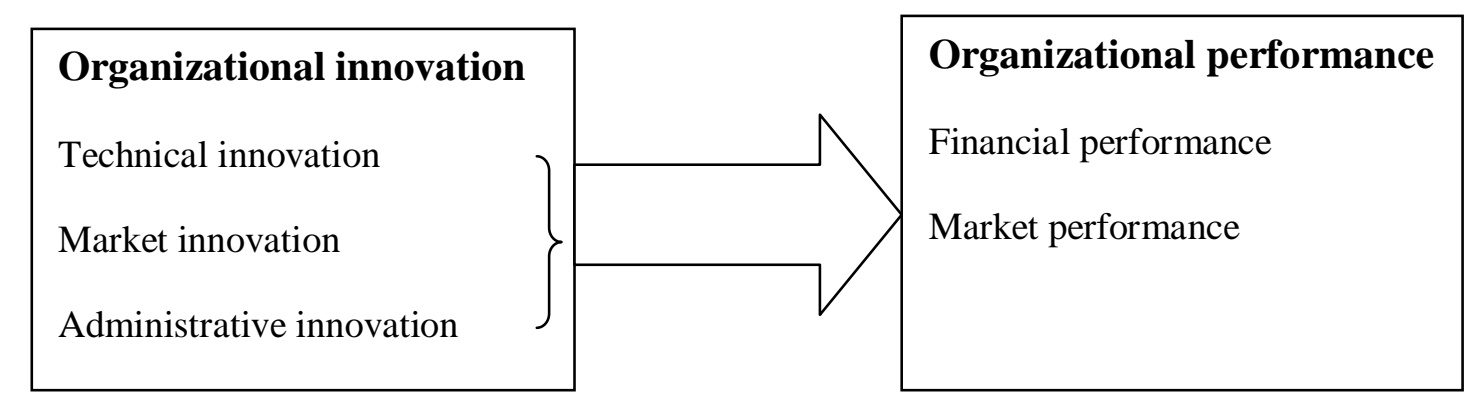




\section{Research Methodology \\ 3.1 Questionnaire Design}

The questionnaire encompasses four parts. These are learning, organizational innovation, performance and demography.

\subsection{Research Constructs Operationalization}

To check the suggested study hypotheses, multi-item levels were taken up from preceding investigations for the estimation of the study constructs. They are operational zed as follows:

\subsection{Learning Construct}

Following Calontone et al (2002), the learning is operational zed as 2nd alignment construct. The first-order signs are firm promise to knowledge, distributed dream, permissiveness, and the intra-organizational information giving out. The dedication towards learning is a stage to which an association encourages learning and also is eager to cultivate learning setting (Calontone, et al., 2002).The Shared dream interconnect the undertakings of workers and evolves connections founded on the substitute of data and distributed mental forms (Akgun, Keskin, Byrne \& Aren, 2007). However, broad mindedness mentions to proficiency of companies to accept new concepts, and the enthusiasm to inquiry stretched lived assumptions concerning demeanor and happenings (Akgun, et al., 2007; Santos-Vijande et al., 2005). To end with, Intra organizational information distributing mentions to joint convictions or behavioral usual actions that are connected to disperse of learning inside a firm (Moorman \& Miner, 1998).

\subsection{Innovation Construct Operationalization}

Assessing innovation, the study applies Popadiuk and Choo's (2006) scale. This scale is comprised of: technological innovation, market innovation as well as administrative innovation. The technological innovation mentions to merchandise, method. The market innovation mentions to cost, advancement, and location innovation. Whereas Administrative innovation indicates scheme, structure, schemes, and heritage innovation.

\subsection{Performance Construct Operationalization}

On the base of the literature check, organizational performance study engages couple aspects, economic and market performance. The financial performance is the measure of effectiveness, ROI and growth in sale volume. Market features the degree to which customers are satisfied and enhances the market share giving more profit ratio as compare to competitors.

\subsection{Research Sample}

The sampling frame comprised of the public sector universities in Khyber Pukhtunkhwa, Pakistan. The sampling frame is limited to include five public sector universities in Peshawar, Khyber Pukhtunkhwa. The research dealt 200 questionnaires. Among those, 102 valid answers were found which bill for an answer rate of around $51 \%$. Here the effect of un-responded analysis strengthens the view of the absence of unresponse bias. The outcome illustrate that dissimilarity prevails between the two. In Table 1 is demonstrated descriptive statistics constructs. 


\section{Results}

The study integrates two groups of analyses. The First is Pearson correlation test, the association of organizational innovation and learning as well as organizational learning and performance. Subsequently, multiple stepwise regression investigation is to be presented to set up the Projecting power of learning on innovation, and then innovation on performance. The Components of learning are dependent variables whereas the components of innovation is the independent variables.

\subsection{Reliability and Validity}

Reliability and Validity are tested for every single of the three with multivariate measures. The multivariate scales are used to estimate the inner consistency by the adoption of Cronbach's alpha (Nunnally, 1978). During this examine, the value of Cronbach's $\alpha$ for each constructs is $>0.8$ as we know that the standard value must be greater than 0.7 given in (Table I), recommending a forceful reliability for our instrument (Cuieford, 1965). In supplement, estimates with item-to-total correlations expanded than 0.6 are examined to have high criterion validity (Kerlinger, 1999). In our study, the itemto-total correlation of each estimate is at least 0.56 recommending that the criterion validity for each scale is satisfactory.

Table 1: The Descriptive statistics of the all constructs learning, innovation and performance

\begin{tabular}{|lllll|}
\hline Dimension & No of item & Mean & SD & Cronbach's $\alpha$ \\
\hline Organization learning & 18 & 3.5 & 0.43 & 0.88 \\
Organization innovation & 35 & 3.7 & 0.45 & 0.95 \\
Organization performance & 19 & 3.4 & 0.52 & 0.92 \\
\hline
\end{tabular}

In attachment, exploratory factor analysis is executed to make sure the instrument has plausible construct. Also using principal element analysis and varimax rotation, factors with nineteen values $>$ than one were preserved. The Cronbach $\alpha$ coefficient of each construct has superseded 0.7 as per Table 2, which mark a comparatively excellent reliability.

Table 2: Internal consistency values and Factor Analysis of the questionnaire

\begin{tabular}{|llllll|}
\hline Dimension & Factor & $\begin{array}{l}\text { Variance } \\
(\%)\end{array}$ & $\begin{array}{l}\text { Cumulative } \\
(\%)\end{array}$ & $\begin{array}{l}\text { Item-to-total } \\
\text { correlation }\end{array}$ & $\begin{array}{l}\text { Cronbach's } \\
\alpha\end{array}$ \\
\hline Organization & Commitment to & 42.38 & 42.38 & 0.62 & 0.92 \\
learning & learning Shared & 7.62 & 50.00 & 0.81 & 0.95 \\
& vision & 6.03 & 56.03 & 0.70 & 0.91 \\
& Open mindedness & 5.39 & 61.42 & 0.72 & 0.90 \\
& Intra- & & & & \\
& organization & & & & \\
& Knowledge & & & & \\
Organization & Sharing & & & & 0.97 \\
innovation & Mechnological & 47.55 & 47.55 & 0.74 & 0.96 \\
& Market & 14.08 & 61.63 & 0.76 & 0.94 \\
Organization & Market & 68.44 & 68.44 & 0.78 & 0.93 \\
\hline
\end{tabular}




\begin{tabular}{llllll}
\hline performance & $\begin{array}{l}\text { performance } \\
\text { Financial }\end{array}$ & 16.01 & 84.45 & 0.81 & 0.92 \\
& performance & & & \\
\hline
\end{tabular}

The resulting linear regression and with adjusted R2 and coefficient or standardized beta are shown in Table 3.

Table 3: Regression Analysis

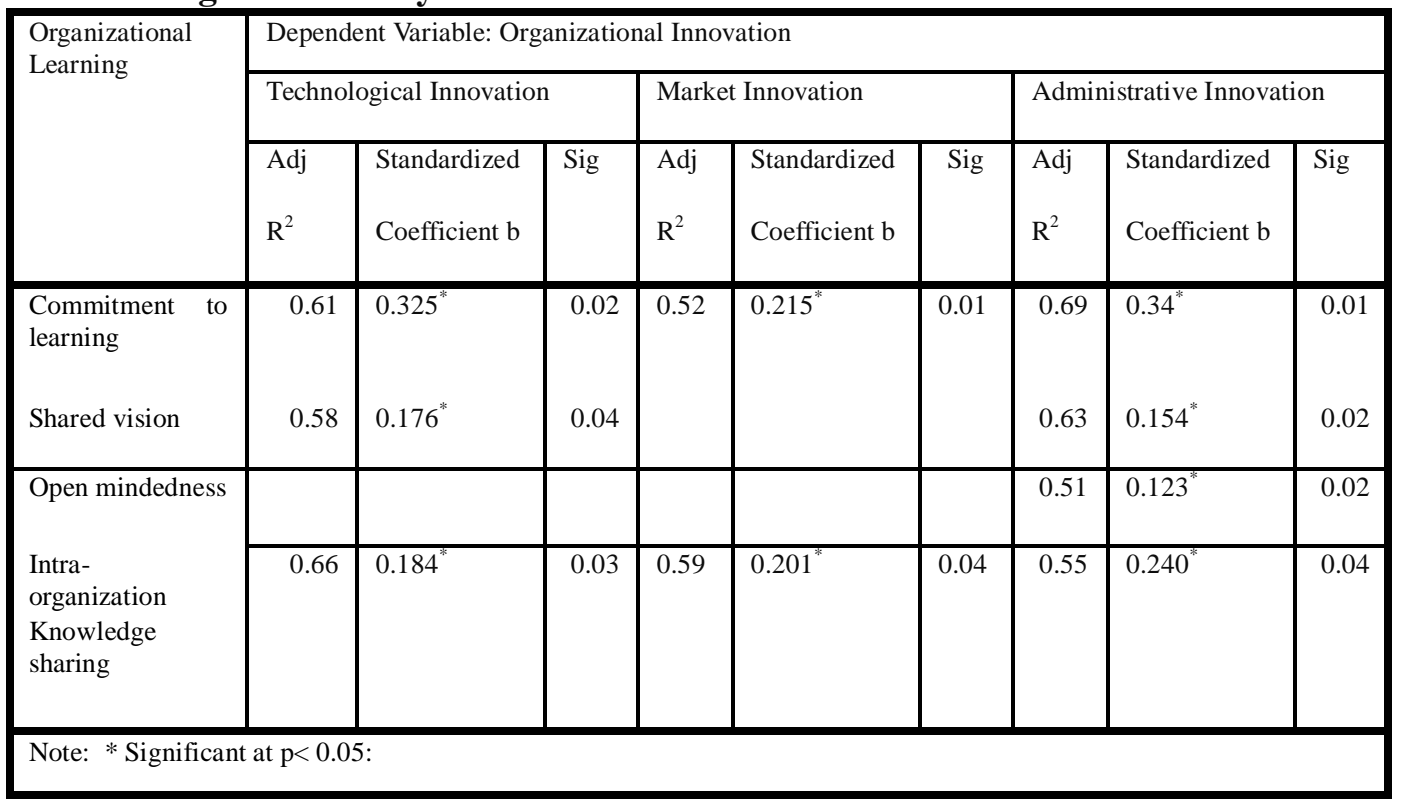

Table 3: The technological innovation used as factor of organization innovation, three factors of organization learning shows positive significant relation with $\mathrm{OI}$ in the regression model

Which were CL, SV and IO Kintra-organizational knowledge distribution? Thus , suggests that $\mathrm{CL}$ that is dedication to learning has the most significant force over technological innovation because its coefficient is 0.325 which is greater than as compare to the other types of innovation coefficient values as well as P. value of commitment to learning is also minimum the other factors. Now for factor market innovation, there were two factors which show positive significant impact on market innovation, these two factors are CL and IOK knowledge, for market innovation commitment to learning is more significant to IOK because its coefficient (0.215) is higher than the coefficient of IOK which is (0.201) and its $\mathrm{P}$ value is also less than IOK but both have positive significant affect on market innovation which is factor of OI. Finally, administration innovation used as factor for OI, regression analysis results confirm all the 4factors of learning which were learning to commitment, share vision, the open mindedness and intra organizational knowledge show positive significant affect on Organization innovation, if we look at the result commitment to learning has $(\beta=0.34)$ which is higher than the other factor this show that commitment to learning highly influence organization innovation. And this result accept alternative hypothesis H1 that organizational learning has appreciably more positive relation to organization innovation. As we are with multiple 
stepwise regression analysis, the research also attempts to explain the result of Organization innovation OI as independent variables for all factors of Organizational performance dependent variables. The following table shows the regression analysis with the coefficients of determinations (R2) with coefficient beta's.

Table 4. Regression analysis of organizational performance as depended variable with organizational innovation as independent variable.

\begin{tabular}{|c|c|c|c|c|}
\hline \multirow{3}{*}{$\begin{array}{l}\text { Organizational } \\
\text { Innovation }\end{array}$} & \multicolumn{4}{|c|}{ Dependent Variable: Organizational Performance } \\
\hline & \multicolumn{2}{|c|}{$\begin{array}{l}\text { Financial/Monetary } \\
\text { performance }\end{array}$} & \multicolumn{2}{|c|}{ Market performance } \\
\hline & $\begin{array}{l}\text { Adjusted } \\
\mathrm{R}^{2}\end{array}$ & $\begin{array}{l}\text { Standardized } \\
\text { Coefficient b }\end{array}$ & $\begin{array}{l}\text { Adjusted } \\
\mathrm{R}^{2}\end{array}$ & $\begin{array}{l}\text { Standardized } \\
\text { Coefficient } b\end{array}$ \\
\hline Technological Innovation & 0.65 & $0.31^{*}$ & 0.50 & $0.31^{*}$ \\
\hline Market Innovation & 0.46 & $0.21^{*}$ & 0.72 & $0.42^{*}$ \\
\hline $\begin{array}{l}\text { Administration } \\
\text { Innovation } \\
\text { Note: * Significant at } \mathrm{p}<\end{array}$ & $\begin{array}{l}0.56 \\
.05:\end{array}$ & $0.25^{*}$ & & \\
\hline
\end{tabular}

Table 4 show that technological innovation (process and product) and market innovation both have positive significant affect on market and financial performance. But if we look at the results of technological innovation $(\mathrm{R} 2=0.65)$ and coefficient $\beta$ is 0.31 this clearly show that technological innovation has positive significant affect on financial performance, on the other hand for market performance, market innovation has very strong positive effect on it. Because coefficient of determination $R^{2}$ is 0.72 and coefficient $\beta$ is 0.42 of market innovation which is higher than the other one, This study is consistent and unswerving with previous research study like that of Van Auken, Madrid-Guijarro and García-Pérez-de-Lema (2008), who examine the relationship between the innovation which is measured with regards of innovation in processes, products and administrations) and with performance, for which 1,091 sample of Spanish manufacturing organizations is used. Their results confirm that innovation significantly and positively impacts organizations performance in low and high technology industries.

\section{Conclusion and Suggestions}

The empirical outcomes supply substantiation for the first hypothesis and disclose that learning is vital for innovation. Therefore this verdict is aligned with preceding empirical investigations that display affirmative connection between organizational learning direction and its innovative ability. For demonstration, Calantone et al (2002) revised the influence of learning utilizing four variables on some US firms. The outcome proposes an affirmative influence of learning orientation on firm discovery 
utilizing route analysis. Likewise, Ussahawanitchakit (2008) discovered that shared dream, open-mindedness or permissiveness, and intra organizational information distributing have important affirmative and direct consequences on accounting organizations innovation direction. Regarding the significance of organizational learning, several procedures can be suggested to investigators and practitioners. A pledged association to innovation endeavors to profoundly realize its natural environment that encompasses the clients, competitors, and appearing technology. Furthermore, Innovation engages the desire to take up new thoughts. This entails that affirmative discovering weather is precious for companies that request to exceed its competition the course of diverse innovativeness. Thus heads and managers ought to conceive and promote the enthusiasm to innovate amidst their workers in order that they evolve new abilities and contribute to living knowledge.

The study furthermore affirms the affirmative connection between organization innovation ability and its performance. The finding is reliable with preceding theoretical investigations (e.g. Cohen \& Levinthal, 1990; Hedlund, 1994; March, 1991) and pragmatic study (e.g. Carol \& Mavis, 2007; Jiménez-Jiménez \& Sanz-Valle, 2010; Pett \& Wolf,2011; Terziovski, 2010). The outcomes can be helpful in assisting companies to realize the vital connection between innovation and performance. While presentation is a centered anxiety to all companies, comprehending the correlation between presentation and innovation may assist companies evolve better comparable strategies. Outcomes of our study may furthermore isof concern to advisors and bureaus that supply aid organizations. The more the comprehending of the significance of innovation, the larger will be the imminent into how companies can accomplish better comparable schemes and performance. Outcomes of the study establish that impact of innovation is not restricted to reputable or huge companies which relish considerable finances of scale.

\section{References}

Akgun, A., Keskin, H., Byrne, J. C., \& Aren, S. (2007). Emotional and Learning Capability and Their Impact on Product Innovativeness and Firm Performance.Technovation, 27(9), 501-513

Argyris, C., \& Schön, D. A. (1978). Organizational learning: A theory of action perspective. Addison-Wesley Publishing company: Reading, MA: AddisonWesley.

Argyris, C. (1994). Good Communication that Blocks Learning. Harvard Business Review. 72(4), 77-85.

Baker, W., \& Sinkula, J. (1999). Learning Orientation, Market Orientation, and Innovation: Integrating and Extending Models of Organizational Performance. Journal of the Academy of Marketing Science, 27(4), 411-427

Bates, R., \& Khasawneh, S. (2005). Organizational learning, learning culture, learning climate and perceived innovation in Jordanian organizations. International Journal of Training and Development, 9(2), 96-109

Bueno, E., \& Ordoñez, P. (2004). Innovation and learning in the knowledge-based economy: challenges for the firm. International Journal of Technology Management, 27 (6/7), 531-533. 
Calontone, R., Cavusgil, S., \& Zhao, Y. (2002). Learning orientation, firm innovation capability, and firm performance. Industrial Marketing Management, 31(6), 515524.

Carol Y., \& Mavis, Yi-Ching. (2007). Does innovation lead to performance? An empirical study of SMEs in Taiwan. Management Research News, 30(2), 115132.

Cefis, E., \& Marsili, O. (2005). A matter of life and death: innovation and firm survival. Industrial \& Corporate Change, 14, 1167-1192

Child, C., Faulkner, D., \& Tallman, S. (2005). Cooperative Strategy. Oxford: Oxford University Press.

Chirico, F., \& Salvato, C. (2008). Knowledge Integration and Dynamic Organizational Adaptation in Family Firms. Family Business Review, 21 (2), 169-181.

Nunnally, J.C. (1978). Psychometric Theory. McGraw-Hill: New York, NY.

Ortenblad, A. (2001). On differences between organizational learning and learning organization, The Learning Organization, 8(3), 125-33.

Pett, T.L., \& Wolff, J.A. (2011). Examining SME performance: The role of innovation, $\mathrm{R} \& \mathrm{D}$, and internationalization. International Journal of Entrepreneurial Venturing, 3(3), 301-314.

Popadiuk, S., \& Choo, C. W. (2006). Innovation and knowledge creation: How are these concepts related?International Journal of Information Management, 26 (4), 30212

Rahim, M. A. (2001). Managing conflict in organizations (3rd ed.). Westport, Conn.: Quorum Books.

Ries, K., \& Trout, N. (1981). Dimensions of innovation in the hospitality industry. International Journal of Contemporary Hospitality Management, 9 (7), 273-86.

Roy, S. (2005). Globalization, ICT and developing nations: challenges in the information age. New Delhi: SAGE Publications.

Santos-Vijande, M., Sanzo-Pirez, M., Plvarez-Gonzalez, L., \& Casielles, R. V. (2005). Organizational learning and market orientation: interface and effects on performance. Industrial Marketing Management, 34, 187-202.

Senge, P. M. (1990). The fifth discipline: the art and practice of the learning organization. New York:

Doubleday Currency. Shefer, D., \& Frenkel, A. (2005). R\&D, firm size and innovation: an empirical analysis. Technovation, 25(1), pp.25-32. 